\title{
Should HIV and AIDS workplace programmes still be advocated in the automotive industry?
}

\begin{tabular}{|c|c|}
\hline \multicolumn{2}{|c|}{$\begin{array}{l}\text { Authors: } \\
\text { Liana Steenkamp }^{1} \\
\text { Jill von der Marwitz } \\
\text { Friederike Baasner-Weihs }^{1,2} \\
\text { Jacques Pietersen }\end{array}$} \\
\hline $\begin{array}{l}\text { Affiliations: } \\
{ }^{1} \text { HIV/AIDS Res } \\
\text { Nelson Mand } \\
\text { University, So }\end{array}$ & $\begin{array}{l}\text { earch Unit, } \\
\text { la Metropolitan } \\
\text { th Africa }\end{array}$ \\
\hline \multicolumn{2}{|c|}{$\begin{array}{l}{ }^{2} \text { Deutsche Gesellschaft } \\
\text { für Internationale } \\
\text { Zusammenarbeit (GIZ) GmbH } \\
\text { Multisectoral HIV Prevention } \\
\text { Programme, Automotive } \\
\text { Industry Development } \\
\text { Centre Eastern Cape, } \\
\text { South Africa }\end{array}$} \\
\hline \multicolumn{2}{|c|}{$\begin{array}{l}\text { 3unit of Statistical } \\
\text { Consultation, Nelson } \\
\text { Mandela Metropolitan } \\
\text { University, South Africa }\end{array}$} \\
\hline \multicolumn{2}{|c|}{$\begin{array}{l}\text { Correspondence to: } \\
\text { Liana Steenkamp }\end{array}$} \\
\hline \multicolumn{2}{|c|}{$\begin{array}{l}\text { Email: } \\
\text { liana.steenkamp@nmmu.ac.za }\end{array}$} \\
\hline \multicolumn{2}{|c|}{$\begin{array}{l}\text { Postal address: } \\
\text { PO Box 77000, Port } \\
6031 \text {, South Africa }\end{array}$} \\
\hline \multicolumn{2}{|c|}{$\begin{array}{l}\text { Dates: } \\
\text { Received: } 25 \text { Nov. } 2013 \\
\text { Accepted: } 21 \text { Oct. } 2014 \\
\text { Published: } 26 \text { Mar. } 2015\end{array}$} \\
\hline \multicolumn{2}{|c|}{$\begin{array}{l}\text { How to cite this article: } \\
\text { Steenkamp, L., Von der } \\
\text { Marwitz, J., Baasner-Weihs, } \\
\text { F., \& Pietersen, J. (2015). } \\
\text { Should HIV and AIDS } \\
\text { workplace programmes } \\
\text { still be advocated in the } \\
\text { automotive industry? SA } \\
\text { Journal of Human Resource } \\
\text { Management/SA Tydskrif vir } \\
\text { Menslikehulpbronbestuur, } \\
\text { 13(1) Art. \#609, } 10 \text { pages. } \\
\text { http://dx.doi.org/10.4102/ } \\
\text { sajhrm.v13i1.609 }\end{array}$} \\
\hline \multicolumn{2}{|l|}{ Read online: } \\
\hline 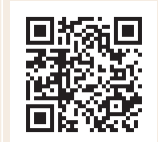 & $\begin{array}{l}\text { Scan this QR } \\
\text { code with your } \\
\text { smart phone or } \\
\text { mobile device } \\
\text { to read online. }\end{array}$ \\
\hline
\end{tabular}

Orientation: In light of the human immunodeficiency virus (HIV) pandemic, and in order to improve competitiveness in the South African private sector, many structures have implemented subsidised workplace programmes.

Research purpose: The aim of this study was to collect baseline data regarding the knowledge, attitudes, practices and belief (KAPB) of employees in the automotive industry in relation to HIV and AIDS, in order to assess the need for HIV and AIDS workplace programmes.

Motivation for the study: Given the abundance of HIV and AIDS information, the question is whether these workplace programmes' efforts are still relevant.

Research design, approach and method: A quantitative descriptive study design was used using a self-administered questionnaire covering questions about KAPB with regard to HIV and AIDS. The data collection took place in seven automotive supplier companies in South Africa $(n=733)$ who were going to implement HIV and AIDS workplace programmes with the support of the Automotive Industry Development Centre in the Eastern Cape.

Main findings: High-risk behaviour, as indicated by sexual relations with more than one partner in the last 12 months, occurred in between 12\% (management) and $42 \%$ (cleaners) of employees. All risk behaviour indicators showed significant differences $(p<0.05)$ between management and administrative staff on the one hand and technicians, operators and cleaners on the other. Despite being aware of an HIV policy, more than $50 \%$ of employees indicated that they would not be willing to disclose their status.

Practical/managerial implications: As HIV and AIDS risk behaviour and stigma remain a problem, HIV infection with associated health problems may threaten productivity in the automotive industry if no measures are taken to address the impact on employees and the company.

Contribution: This study strongly supports the conclusion that KAPB studies can still provide important information to tailor HIV workplace programmes according to employee needs.

\section{Introduction}

The automotive industry employs a large workforce in the Eastern Cape province of South Africa where the high incidence and prevalence of HIV, especially in the age group 18-49 (Health Systems Trust, 2013) remains a threat to employees' health. After years of HIV prevention campaigns, industry often assumes that employees are familiar with HIV and AIDS, have developed favourable attitudes and consequently have improved their risk behaviour. However, this may not be the case and there is a paucity of recent data concerning HIV and AIDS within the workplace in South Africa. The aim of this study was to determine whether there is a need to improve knowledge, attitudes, beliefs and practices as part of HIV and AIDS workplace programmes, specifically within the automotive industry.

Despite global, national and regional efforts to prevent new HIV infections and to lower the number of AIDS-related deaths (UNAIDS, 2009), the pandemic continues to threaten employee health as well as organisations' competitiveness and profits (United Nations Department of Economic and Social Affairs/Population Division, 2009). For instance, Van Zyl and Lubisi (2009) describe a rising trend in the incidence of HIV and AIDS in the manufacturing sector of the South African economy, with a consequent negative impact on skill levels, productivity, labour costs and production costs. This trend is despite the fact that many larger companies are more aware of the threat of this pandemic and commit resources towards managing HIV and AIDS in the workplace through appropriate programmes (Global Business Coalition [GBC] \& International Finance Corporation [IFC], 2010). However, such efforts seem to focus and report more on the 
cost and impact of HIV and AIDS treatment programmes for employees (Setswe, 2009) than on HIV prevention programmes. Yet, according to the Employment Equity Act (Act No. 55 of 1998, Department of Labour, 2000), HIV and AIDS workplace programmes are one of the most effective ways of reducing the impact of HIV and AIDS in the workplace. The Automotive Industry Development Centre - Eastern Cape (AIDC EC) is in the process of marketing and implementing subsidised HIV and AIDS workplace programmes within the manufacturing sector of the automotive industry. Targeting mainly small and medium supplier companies, the proposed programme, supported by the Deutsche Gesellschaft für Internationale Zusammenarbeit (GIZ), places a strong focus on HIV prevention.

In 2009 the component manufacturing industry reported having 61000 employees in South Africa (Johannesburg Motor Show, 2013). According to the Eastern Cape Development Corporation (ECDC, 2013), the automotive sector in the Eastern Cape accounts for more than 40000 formal jobs, 10000 of which are at original equipment manufacturers (OEMs) and 30000 at the 1500 supplier companies. Since the seven OEMs operating in South Africa as well as up to 100 major component manufacturers are located in the Eastern Cape, this province, with an estimated HIV prevalence of $12.2 \%$ (Shisana et al., 2014), is of strategic importance as a location to the industry. More recent moves to initiate HIV and AIDS workplace programmes need to be considered against the background of existing interventions. In an assessment amongst 74 automotive companies in South Africa, more than half (52\%) of the surveyed organisations have implemented holistic workplace wellness programmes (WWP) irrespective of organisation size. The results also indicated that support exists for HIV and AIDS to be incorporated into WWP rather than addressing it separately (Meyer-Weitz, Weihs \& Baasner-Weihs, 2012). The question is whether all the efforts to address HIV and AIDS in this industry are necessary and relevant in a country with an apparent widespread awareness regarding HIV risk and risk behaviour.

Companies that have conducted a knowledge, attitude, practices and belief (KAPB) survey amongst their workforce have found it to be a very useful practice for the development, monitoring and evaluation of HIV programmes (Price Waterhouse Coopers, 2013; Rukambe, 2010). KAPB studies may provide important baseline information on whether HIV risk behaviour and associated stigma are prevalent amongst employees in the automotive industry and assist with the development of relevant HIV and AIDS workplace programmes. However, older research by South African Business Coalition on HIV and AIDS (SABCOHA) and Bureau for Economic Research (BER) (2003) has shown that only $14 \%$ of companies surveyed have conducted research in relation to the impact of HIV and AIDS on their labour force and that most of those were larger companies.

A more recent survey by the AIDC EC (2009) indicated that $72 \%$ of automotive component manufacturing companies surveyed have implemented an HIV and AIDS workplace policy. The majority of companies who managed to translate HIV and AIDS policies into HIV and AIDS workplace programmes had large staff turnovers, whilst smaller companies lacked the budget to implement similar programmes. More than $50 \%$ of companies with HIV and AIDS workplace programmes did not monitor the efficacy of these programmes. This supports the finding that although most work organisations in South Africa recognise the existence and impact of HIV and AIDS, they do not consider that they are affected (International NGO Training and Research Centre [INTRAC], 2008). Many organisations mistakenly assume that employees know about HIV and AIDS, including prevention methods, and that this knowledge is translated into practice in their private lives. However, literature indicates that this might not always be the case (INTRAC, 2008); thus, awareness campaigns in the workplace can contribute towards improving HIV risk behaviour (Chimbetete \& Gwandure, 2011). An HIV and AIDS workplace programme typically includes an HIV and AIDS awareness campaign focusing on HIV prevention, voluntary testing, counselling, care and support for HIVinfected employees, protection of employees from stigma and monitoring and evaluation of the programme. HIV and AIDS workplace programmes, in the context of the present research, do not refer to management of the infection with appropriate antiretroviral therapy.

The objectives of this study were to determine employees' knowledge about the transmission and visibility of symptoms, the prevention and treatment of HIV and AIDS, awareness of workplace policies, employees' sexual attitudes and practices and the relationships between job-specific skill levels and risk behaviour, as well as HIV-associated stigma. By reaching these objectives, a contribution will be made to an identified research need into the relevance of KAPB surveys in the context of $\mathrm{HIV}$ in the workplace in the South African automotive industry. The data obtained will indicate whether sexual risk behaviour is a concern amongst different skill levels in this sector and assist programme managers to develop and target appropriate HIV workplace programmes to address risk behaviour and stigma.

\section{Literature review}

\section{HIV and AIDS in the South African workplace}

The HIV and AIDS epidemic continues to target the most productive workforce, namely those between 15 and 49 years of age (International Labour Organisation, 2009). The International Labour Office (ILO, 2006) estimated in 2005 that 3.6 million South African labour force participants between the ages of 15 and 65 were HIV-positive. Colvin, Connolly and Madurai (2007) describe an HIV prevalence of $10.9 \%$ between 1999 and 2005 from data collected from 22 workplace surveys amongst more than 21000 employees in South Africa. Although HIV prevalence decreased from 2005 to 2007 (Department of Health, 2008), South Africa still has one of the highest workforce HIV and AIDS statistics 
in the world, with a huge impact on businesses in hard-hit regions (SABCOHA, 2014, p. 4).

One may assume that the HIV prevalence is higher in the unskilled labour force than skilled categories, but the relationship between HIV prevalence and skill level remains inconclusive. Whilst the HIV prevalence in some studies has been higher in unskilled or semi-skilled labour than in highly skilled labour categories (Colvin, Connolly \& Madurai, 2007; Quattek, 2000; Shisana \& Simbayi, 2002; Thurlow, Gow \& George, 2009), earlier studies confirmed a constant HIV risk across all skill levels (Acott, 2000). As HIV and AIDS can affect all skill levels in companies, it may affect organisational efficiency (Fraser, Grant, Mwanza \& Naidoo, 2002) as well as profitability (Lisk, 2002).

Daimler Chrysler established that the money saved by preventing a new infection in its South African workforce ranged from $\$ 25000$ to $\$ 280000$, depending on the skill level (Neilson, 2005). Smaller companies seem to be less concerned about the cost or impact of HIV and AIDS for the company, because they have less capacity to respond to the threat (Rosen, Feeley, Connelly \& Simon, 2007). It is vital that companies understand the value of HIV prevention, by comparing the cost of HIV workplace programmes with the cost of increased absenteeism, staff turnover, recruitment and training costs, medical care, insurance, retirement funds and funeral costs (George, Surgey \& Gow, 2014).

\section{International and national trends to address the effect of HIV and AIDS}

International funding from the United States of America assisted in 2004 with the launch of the President's Emergency Plan for AIDS Relief (PEPFAR), which enabled the start of the antiretroviral therapy programme in South Africa. PEPFAR announced that the funding would be halved over 5 years to 2017, which would cause the majority of staff paid by PEPFAR to return to the government sector (Health Systems Trust, 2013).

Increases in government spending were observed between 2009 and 2012 owing to the new early treatment threshold of a CD4 count of 350 cells/ $\mu \mathrm{L}$ to qualify for antiretroviral therapy (National Treasury, 2013). It is important to realise that the majority of funding is channelled into the antiretroviral drug programme, which includes prevention of mother-to-child transmission and therefore has very little effect on prevention programmes in the workplace.

Over the years, many companies have been slow to recognise the threats to profits posed by HIV and AIDS. It is, however, the company's responsibility to adopt a healthy well-defined commitment to protect and support their employees and the workplace is an ideal place in which to disseminate prevention messages (SABCOHA, 2012). Multi-sectoral responses are mandatory to effectively address the impact of HIV and AIDS. Currently, most HIV workplace programmes refer to a range of company-based interventions including an HIV policy, HIV counselling and testing (HCT) and the referral for treatment to local community clinics if necessary (Department of Labour, 2000).

\section{Risk factors and stigma}

To optimally explain HIV and AIDS stigma and potential intervention strategies, the Link and Phelan's model (Link \& Phelan, 1995) may be explored to provide insight into the processes that cause health inequalities amongst members of groups that may be stigmatised. Stigma, also defined as labelling, stereotyping, status loss and discrimination (Link \& Phelan, 2001), may be linked to discrimination at an individual level (unequal treatment) or at a structural level (loss of opportunities). Other social forces such as poverty, sexism and racism, may create overlapping and reinforcing stigmatised conditions, thus limiting access to treatment, care and support. Standardised sets of stigma measures, or indicators, would enable tracking of stigma burden over a period of time (Van Brakel, 2006). Measurable indicators could also be useful to detect if programmes or policies are inadvertently exacerbating HIV stigma in the workplace. At the moment, indicators to monitor stigma, developed by the United Nations, are available and are used mainly for research purposes. These indicators measure the sociocognitive aspects of HIV and AIDS stigma, for example the respondents' willingness to interact with persons living with HIV and AIDS (PLWHA), the extent of blame, consideration of blame, as well as perceptions related to the partners, friends, family and community in general, and how they would react if they knew that they were infected with HIV (Mahajan et al., 2008). Little research has systematically measured the HIV and AIDS stigma at the structural and institution levels. Whilst the HIV and AIDS stigma is considered a major facilitator of the epidemic, as well as self-stigmatisation (Hatzenbuehler, Phelan \& Link, 2013), very few studies have demonstrated an association of stigma and increased risk behaviour. Stigma, testing and treatment is documented as a barrier to uptake in HIV testing and treatment services in numerous settings including South Africa (Dlamini et al., 2009), where individuals who were not tested for HIV exhibited significantly greater stigmatising attitudes toward PLWHA.

Recent surveys reveal that there is an association between training intervention and HIV and AIDS risk reduction, with improved attitudes toward condom use (Becker, 2010; Chimbetete \& Gwandure, 2011, p. 16) and improved sexual risk cognition (Becker, 2010; Chimbetete \& Gwandure, 2011; East, Jackson, Peters \& O’Brien, 2010). More importantly, most studies indicate that these HIV training programmes are strongly associated with a reduction in HIV-associated stigma and improved willingness to disclose HIV status (Chimbetete \& Gwandure, 2011; Gilbert \& Walker, 2010).

\section{Knowledge, attitudes, practices and beliefs relating to HIV and AIDS}

The AIDS risk reduction model is concerned with people's efforts to change sexual risk behaviours related to HIV infection. There are three stages in the model, the first being 
recognition and labelling of certain sexual behaviours as high risk for contracting HIV. In this knowledge phase, people use information to reduce their risky sexual behaviours. The second stage involves making a commitment to female participants to reduce high-risk activities, for example by using a condom. The third phase is the development of coping skills to sustain empowerment by engaging with development interventions (Noar, 2007). This stage is broken down into three main strategies, namely continuously obtaining correct information, developing social coping mechanisms and acting on solutions to difficult situations like negotiating safer sex (Catania, Kegeles \& Coates, 1990).

KAPB surveys may contribute in measuring the information coping mechanisms and actions by identifying needs, problems and barriers in programme delivery, as well as solutions for improving quality and accessibility of services (Global Business Coalition on HIV/AIDS, tuberculosis and malaria). The data collected enable programme managers to set workplace programme priorities, to estimate resources required for various activities, to select the most effective communication channels and messages, to establish baseline levels and to measure change that results from interventions and allow for advocacy. To serve as an effective monitoring instrument, questionnaires for KAPB surveys have to be carefully designed in order to use the same questionnaire over several years.

The implementation of KAPB studies focusing on employees is increasing, even though in the past such studies only focused on students, professionals and the public (Rukambe, 2010). According to Mahajan, Colvin, Rudatsikira and Ettl (2007), monitoring and evaluation remain a challenge and further research on workplace programmes resulting in the development of monitoring and evaluation strategies in respect of HIV and AIDS workplace policies is urgently required. Research to determine gaps in knowledge or barriers to change attitude and behaviour is vital to develop appropriate workplace programmes, particularly in smaller companies. The implementation of appropriate HIV workplace programmes may play a greater role in HIV prevention of employees, with obvious economic benefit to companies.

Associated research can serve as an important entry to improve the understanding of the economic and social impact of the epidemic as well as providing a sound basis for supportive services. Literature has shown that in most African countries, employees still felt discriminated against when HIV status was disclosed (Maughan-Brown, 2010; Sprague, Simon \& Sprague, 2011).

In the context of the abovementioned information, it is necessary to determine whether HIV risk behaviour and HIV-associated stigma are concerns that companies need to address. The following research questions are thus posed: Is HIV risk behaviour a concern in smaller automotive companies? Are there differences between behaviour and attitudes amongst the different skill levels? Is HIV-associated stigma still present in companies, given the fact that the majority of South African companies have adopted an HIV policy?

For this study, the researchers hypothesised that HIV risk behaviour and associated stigma are still challenges that need to be addressed in the automotive industry and that these challenges may be associated with certain skill levels. The hypothesis that information from KAPB studies can contribute to the content of HIV workplace programmes was also investigated.

\section{Method}

\section{Research approach}

A quantitative descriptive study design was followed by conducting a KAPB survey. KAPB surveys can identify knowledge gaps, cultural beliefs or behavioural patterns that may facilitate understanding and action, as well as pose problems or create barriers for HIV prevention (World Health Organization, 2008).

\section{Research participants and sampling}

The data collection took place in seven automotive companies in South Africa that will be implementing HIV and AIDS workplace programmes with the support of the AIDC EC. The population was composed of a convenience sample $(n=733)$ of all employees across all skill levels employed at the respective companies at the time of the survey.

\section{Measuring instruments}

A questionnaire was amended from a standardised KAPB survey dealing with HIV and AIDS and previously used for assessment by the AIDC EC. The attitude and belief sections were amended from 'yes' and 'no' answers to a four-point Likert scale ranging from 'strongly disagree' to 'strongly agree', in order to change the questions to be less threatening. All questions were in English. The questionnaire was divided into seven sections: Section A: Biographical Data, Section B: Healthy Lifestyle/Behaviour, Section C: Knowledge and attitudes, Section D: Knowledge of HIV and AIDS Workplace Programmes and Policies, Section E: Access to HIV Counselling and Testing Services, Section F: Care and Support and Section G: Stigma and Disclosure. Sections A to $D$ and $G$ are included in this article. The questionnaire was assessed by an expert panel prior to the research taking place. Before data analysis continued, internal consistency as verified by Cronbach's alpha values was determined. Results showed 0.67 for Section B: Healthy Lifestyle/Behaviour, 0.74 for Section C: Knowledge and attitudes and 0.71 for Section G: Stigma and Disclosure. All these values are acceptable for descriptive research.

\section{Procedures}

The questionnaire was distributed by staff from AIDC EC to the whole population at the seven participating companies. To ensure high participation rate and to address possible concerns of employees with regard to the confidentiality 
of the research, the companies' management and HIV and AIDS coordinators briefed all employees during workrelated meetings about the planned research. In addition, each employee received a letter explaining the purpose of the research and emphasising that participation was voluntary and that all questionnaires would be anonymous and confidential. The self-administered questionnaires were handed out to all employees. Employees were requested to hand in the questionnaire within a week. A sealed box was provided for this purpose. In all seven companies, 38\% of employees chose to voluntarily participate in the study (ranging from $26 \%$ to $60 \%$ ).

\section{Statistical analysis}

The data was analysed using MS Excel 2010 and SPSS (version 21). Frequencies and percentages were used to present categorical data. Subgroups were compared using cross-tabulation using the Pearson chi-square test to test for statistical significant differences and Cramer's V as effect size measure to indicate practical significance. Internal consistency was verified with Cronbach's alpha.

\section{Results}

The sample had a mean age of 36.4 years with a standard deviation of 9.2 (only 670 reported their age), with $68 \%$ ( $n=484$ ) being female. Findings indicated that $7 \%$ of the sample were in management positions and only approximately $4 \%$ were working as technicians (Table 1 ).

TABLE 1: Description of sample according to skill level.

\begin{tabular}{llll}
\hline Job category & Number & \% & $\begin{array}{l}\text { \% with college or university } \\
\text { qualification }\end{array}$ \\
\hline Management & 49 & 7.0 & 82 \\
Technician & 31 & 4.4 & 65 \\
Artisan & 40 & 5.7 & 42 \\
Operator & 392 & 55.8 & 19 \\
Administrative & 50 & 7.1 & 56 \\
Cleaner & 30 & 4.3 & 4 \\
Other & 111 & 15.8 & 29 \\
\hline$n=733$. & & &
\end{tabular}

TABLE 2: Percentage high-risk behaviour in various skills level categories.

\begin{tabular}{|c|c|c|c|c|c|c|c|c|c|c|}
\hline Job category & $\begin{array}{l}\text { Management } \\
(n=49)\end{array}$ & $\begin{array}{l}\text { Technician } \\
(n=31)\end{array}$ & $\begin{array}{l}\text { Artisan } \\
(n=40)\end{array}$ & $\begin{array}{l}\text { Operator } \\
(n=392)\end{array}$ & $\begin{array}{l}\text { Administrative } \\
(n=50)\end{array}$ & $\begin{array}{l}\text { Cleaner } \\
(n=50)\end{array}$ & $\begin{array}{l}\text { Other } \\
(n=11)\end{array}$ & $\begin{array}{l}\text { Pearson } \\
\mathrm{chi}^{2}\end{array}$ & $p$-value & Cramer's V \\
\hline$>1$ partner in last 12 months & 12 & 37 & 13 & 31 & 12 & 42 & 28 & 21.97 & $0.001^{*}$ & 0.18 (small) \\
\hline Casual sex outside relationship & 12 & 23 & 8 & 26 & 6 & 41 & 27 & 24.08 & $0.0005^{*}$ & 0.19 (small) \\
\hline Sex whilst under influence of alcohol & 22 & 37 & 40 & 41 & 17 & 39 & 34 & 16.06 & $0.01 *$ & 0.15 (small) \\
\hline Condom use if sex outside relationship & 25 & 15 & 29 & 10 & 20 & 10 & 19 & 18.46 & 0.1 & 0.16 \\
\hline
\end{tabular}

$n=733$.

TABLE 3: Percentage employees with poor knowledge about HIV transmission in various skills level categories.

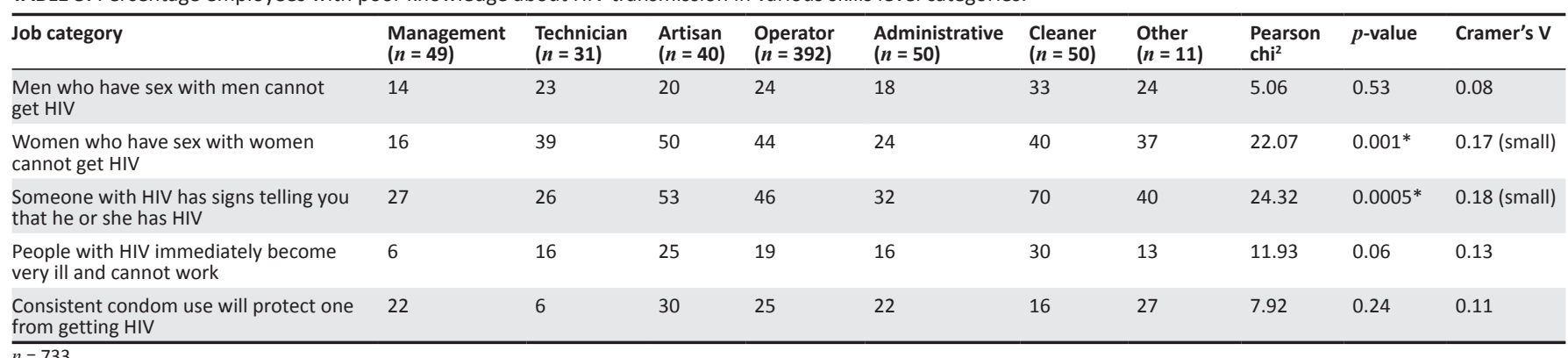

\section{Knowledge, attitude, practices and beliefs outcomes: Risk behaviour}

High-risk behaviour as indicated by sexual relations with more than one partner in the last 12 months still took place in $12 \%$ (management) and 42\% (cleaners) of employees. Similar results for casual sex outside their stable relationship and sex under the influence of alcohol have been demonstrated (Table 2), with all three risk behaviour indicators showing significant differences $(p<0.05)$ between management and administrative staff on the one hand and technicians, operators and cleaners on the other hand. All these differences, however, were of small practical importance (Cramer's V).

\section{Knowledge, attitude, practices and beliefs outcomes: Knowledge}

Inconsistent or poor knowledge about some of the knowledge questions was displayed by up to $70 \%$ of some of the job categories (Table 3). More than $45 \%$ of operators, artisans and cleaners indicated that someone with HIV has signs that will tell you if that person is HIV-positive; these differences were statistically significant $[\mathrm{c} 2(6, n=670)=24.32, p<$ $0.001]$, but only of small practical importance. However, most employees $(n=558 ; 76.1 \%)$ across all categories, were aware that consistent condom use is protective against HIV transmission. In this group, $28.1 \%(n=154)$ still displayed high-risk behaviour (multiple sexual partners) with almost $30 \%$ of them indicating inconsistent or no condom use either with casual partners or their regular partner. A positive outcome was that $73 \%(n=111)$ of those with high-risk behaviour had already undergone an HIV test, indicating some form of risk perception in this group.

\section{Knowledge, attitude, practices and beliefs outcomes: Attitude}

Although fewer than $30 \%$ of employees reported negative attitudes about condom use (Table 4), significantly more

$n=733$. 
TABLE 4: Attitude of employees about HIV and AIDS prevention behaviour amongst various skills level categories.

\begin{tabular}{|c|c|c|c|c|c|c|c|c|c|c|}
\hline Job category & $\begin{array}{l}\text { Management } \\
(n=49)\end{array}$ & $\begin{array}{l}\text { Technician } \\
(n=31)\end{array}$ & $\begin{array}{l}\text { Artisan } \\
(n=40)\end{array}$ & $\begin{array}{l}\text { Operator } \\
(n=392)\end{array}$ & $\begin{array}{l}\text { Administrative } \\
(n=50)\end{array}$ & $\begin{array}{l}\text { Cleaner } \\
(n=50)\end{array}$ & $\begin{array}{l}\text { Other } \\
(n=11)\end{array}$ & $\begin{array}{l}\text { Pearson } \\
\text { chi }^{2}\end{array}$ & $p$-value & Cramer's V \\
\hline Condoms take away sexual pleasure & 24 & 35 & 26 & 34 & 21 & 33 & 36 & 3.56 & 0.73 & 0.07 \\
\hline I do not use condoms for religious reasons & 6 & 6 & 4 & 15 & 7 & 22 & 14 & 7.81 & 0.25 & 0.12 \\
\hline $\begin{array}{l}\text { I do not use condoms - I trust my sexual } \\
\text { partner(s) }\end{array}$ & 46 & 21 & 41 & 27 & 47 & 19 & 38 & 15.67 & $0.01 *$ & 0.16 (small) \\
\hline My partner refuses to allow us to use condoms & 9 & 9 & 28 & 23 & 19 & 37 & 16 & 11.56 & 0.07 & 0.14 \\
\hline Condoms are either too big or small & 6 & 10 & 22 & 27 & 8 & 27 & 24 & 13.83 & $0.03^{*}$ & 0.16 (small) \\
\hline If I was HIV+ I would use condoms & 94 & 97 & 93 & 95 & 96 & 97 & 95 & 1.25 & 0.97 & 0.04 \\
\hline My risky behaviour has changed because of HIV & 29 & 39 & 43 & 52 & 22 & 59 & 46 & 56.03 & $0.00 *$ & $0.2(\bmod )$ \\
\hline I will get treatment if I or my partner gets HIV & 96 & 100 & 95 & 97 & 100 & 100 & 98 & 4.96 & 0.54 & 0.08 \\
\hline
\end{tabular}

TABLE 5: Beliefs of and stigma amongst employees about HIV and AIDS amongst various skills level categories.

\begin{tabular}{|c|c|c|c|c|c|c|c|c|c|c|}
\hline Job category & $\begin{array}{l}\text { Management } \\
(n=49)\end{array}$ & $\begin{array}{l}\text { Technician } \\
(n=31)\end{array}$ & $\begin{array}{l}\text { Artisan } \\
(n=40)\end{array}$ & $\begin{array}{l}\text { Operator } \\
(n=392)\end{array}$ & $\begin{array}{l}\text { Administrative } \\
(n=50)\end{array}$ & $\begin{array}{l}\text { Cleaner } \\
(n=50)\end{array}$ & $\begin{array}{l}\text { Other } \\
(n=11)\end{array}$ & $\begin{array}{l}\text { Pearson } \\
\text { chi }^{2}\end{array}$ & $p$-value & Cramer's V \\
\hline HIV is a punishment & 15 & 23 & 13 & 18 & 4 & 41 & 18 & 31.03 & $0.001^{*}$ & 0.15 (small) \\
\hline HIV is a chronic manageable preventable disease & 85 & 87 & 65 & 73 & 80 & 70 & 82 & 19.22 & 0.08 & 0.11 \\
\hline $\begin{array}{l}\text { People with HIV are like any of us and need } \\
\text { support }\end{array}$ & 92 & 90 & 95 & 96 & 100 & 97 & 97 & 12.15 & 0.43 & 0.09 \\
\hline If you are circumcised you will not get HIV & 4 & 10 & 5 & 8 & 6 & 14 & 4 & 19.04 & 0.09 & 0.11 \\
\hline $\begin{array}{l}\text { If I was HIV+ people would ignore my good } \\
\text { points }\end{array}$ & 19 & 13 & 8 & 31 & 25 & 27 & 27 & 27.87 & 0.06 & 0.11 \\
\hline If I was HIV+ I would keep it secret & 13 & 23 & 15 & 28 & 20 & 27 & 23 & 28.09 & 0.06 & 0.11 \\
\hline $\begin{array}{l}\text { Most people believe that a person with HIV is } \\
\text { dirty }\end{array}$ & 10 & 20 & 15 & 35 & 25 & 34 & 22 & 39.87 & $0.002^{*}$ & 0.13 (small) \\
\hline $\begin{array}{l}\text { People would not want me around their children } \\
\text { if I was HIV+ }\end{array}$ & 10 & 6 & 15 & 25 & 13 & 30 & 16 & 36.82 & $0.005^{*}$ & 0.13 (small) \\
\hline
\end{tabular}

if I was HIVt

TABLE 6: Knowledge amongst employees about HIV and AIDS workplace programmes amongst various skills level categories.

\begin{tabular}{|c|c|c|c|c|c|c|c|c|c|c|}
\hline Job category & $\begin{array}{l}\text { Management } \\
(n=49)\end{array}$ & $\begin{array}{l}\text { Technician } \\
(n=31)\end{array}$ & $\begin{array}{l}\text { Artisan } \\
(n=40)\end{array}$ & $\begin{array}{l}\text { Operator } \\
(n=392)\end{array}$ & $\begin{array}{l}\text { Administrative } \\
(n=50)\end{array}$ & $\begin{array}{l}\text { Cleaner } \\
(n=50)\end{array}$ & $\begin{array}{l}\text { Other } \\
(n=11)\end{array}$ & $\begin{array}{l}\text { Pearson } \\
\text { chi }^{2}\end{array}$ & $p$-value & Cramer's V \\
\hline Awareness about company HIV policy & 83 & 70 & 80 & 75 & 61 & 61 & 69 & 11.01 & 0.08 & 0.13 \\
\hline $\begin{array}{l}\text { Initiatives exist to create awareness about HIV } \\
\text { policy }\end{array}$ & 83 & 87 & 90 & 81 & 75 & 50 & 75 & 21.57 & $0.001^{*}$ & 0.18 (small) \\
\hline A person's HIV status should be confidential & 85 & 90 & 82 & 88 & 96 & 59 & 90 & 26.51 & $0.0001^{*}$ & 0.19 (small) \\
\hline If I were HIV+ I would tell my manager & 54 & 43 & 55 & 49 & 59 & 43 & 46 & 4.31 & 0.63 & 0.08 \\
\hline Company supports people who are HIV+ & 87 & 67 & 70 & 73 & 92 & 58 & 73 & 16.20 & $0.01 *$ & 0.15 (small) \\
\hline $\begin{array}{l}\text { Wellness programmes assist people with HIV to } \\
\text { live longer and continue working }\end{array}$ & 83 & 76 & 84 & 81 & 96 & 78 & 82 & 7.78 & 0.25 & 0.1 \\
\hline
\end{tabular}

$n=733$.

management, administrative staff and artisans [c2(6, $n=670)=15.67, p<0.05]$ reported that they did not use condoms because they trusted their partner. More than $70 \%$ of employees across all categories indicated that they felt it was important for their partner to get tested. More than $90 \%$ indicated that they would use condoms if infected with HIV. Significantly more cleaners, operators and artisans $[\mathrm{c} 2(6, n=670)=56.03, p<0.0001]$ indicated that their risk behaviour had changed as a result of HIV. This outcome had moderate practical importance. Significantly more women than men [c2 $(1, n=670)=5.97, p<0.05]$ thought that condom use decreases sexual pleasure, that condoms break and are not reliable $[\mathrm{c} 2(1, n=670)=9.46, p<0.005]$ and that condom size is inadequate $[\mathrm{c} 2(1, n=670)=11.23$, $p<0.001]$. Younger age groups (18-24 years) displayed significantly more misconceptions about condom use than older age groups; once again, it was of small practical importance.

\section{Knowledge, attitude, practices and beliefs outcomes: Beliefs and stigma}

Significantly $[c 2(6, n=670)=31.03, p<0.01]$ more cleaners than other job categories indicated that HIV was a punishment and findings from all stigma-related statements (Table 5) indicated that the job categories that included cleaners and artisans still struggled against stigma in HIV significantly more than the other categories.

Significantly more employees [c2(1, $n=670)=17.80, p<$ 0.0001] who agreed with the statement that 'they will work hard to keep their HIV status secret' indicated that colleagues avoided HIV-positive people and thus still felt that stigma plays an important role. A similar trend was observed for willingness amongst employees to tell their manager about their HIV status. Although the majority of employees across all skill levels were aware of the HIV policy in their company (Table 6), significantly fewer [c2 $(1, n=670)=21.57, p<0.0005]$ 
in the unskilled labour force indicated that they were aware of the policy. Despite the high percentage of employees who indicated that they were aware of the HIV policy, and agreed that the company would support people who are HIVpositive, only approximately $50 \%$ (Table 6) indicated that they would be willing to disclose their status if they were HIVpositive. A smaller proportion of employees who were aware of HIV and AIDS policies indicated that they believed that employees who were HIV-positive might lose their jobs.

\section{Discussion}

The first aspect that needs to be considered when discussing the results is that the automotive industry is one of the largest manufacturing sectors in South Africa, as it contributes at least $6 \%$ to the gross domestic product (GDP), accounts for almost $12 \%$ of the country's manufacturing exports, and employed approximately 30000 employees in 2013 (National Association of Automobile Manufacturers of South Africa [NAAMSA], 2013). This industry is concentrated in only three regions, highlighting the importance of external economies and customer proximity to the supply chain. The second most important region after Gauteng is the Eastern Cape, covering Port Elizabeth and Uitenhage. This region is home to about $30 \%$ of the national automotive components industry. The South African government has identified the automotive industry as a key growth sector (AIEC, 2014). Whilst certain subsectors are very labour-intensive, the bulk of the motor vehicle, parts and accessories sectors is relatively capital-intensive. Furthermore, the skill requirements of the sector are quite high. Only $50.3 \%$ of total employment in the sector is semiskilled or unskilled, whilst $31.4 \%$ of the workforce belongs in high-level skills (AIDC EC, 2009).

The second aspect is the high HIV prevalence amongst the South African working population. Although recent data suggest that the prevalence rates are stabilising, the high morbidity and mortality rates increase the financial burden of HIV and AIDS, which is an important cost factor to the industry. In light of the above, the aim of this study was to determine the knowledge, attitudes, behaviour and practices of employees in small and medium enterprises in the automotive industry in relation to HIV and AIDS, especially in relation to different skill levels within these companies.

Findings from this study indicate that there are still considerable gaps in knowledge levels amongst the investigated workforce, and that high-risk behaviour is still taking place, especially in the semi-skilled and unskilled workforce. Even amongst those employees with adequate knowledge about HIV transmission, risk behaviour as indicated by inconsistent condom use and multiple sexual partners exceeded 30\%. Despite this, the risk awareness seems high, with $73 \%$ of those with high-risk behaviour indicating that they had already undergone an HIV test.

This indicates that firstly, high knowledge levels do not seem to be sufficient to create behaviour change. This has been supported by literature in the past. Increasing knowledge about HIV and AIDS supports sustaining of risk reduction (Joint United Nations Programme on AIDS [UNAIDS], 2003) but on an individual level HIV and AIDS interventions are only successful if context-specific information and skills are provided (UNAIDS, 1999, p. 17). Secondly, the high testing rates amongst employees with high-risk behaviour seem to indicate that employees are aware of their risk, but do not have the relevant approaches, skills or motivation to reduce their risk. It would be important to find out exactly what keeps study participants from reducing their risk of HIV transmission. Education programmes that participants of this study might have been exposed to do not seem to have addressed their specific needs or provided them with the relevant skills or approaches necessary for them to be able to reduce the risk of HIV transmission. This is reinforced by the attitudes of employees towards condoms, which indicate that the message of condoms as the most important risk reduction strategy, next to abstinence and faithfulness, does not seem to have been adopted by a relevant number of participants in this study.

It is worrying that misconceptions and negative attitudes towards condoms are more prevalent amongst females and younger employees. This may indicate that they need to be targeted as separate groups. Innovative approaches may have to be developed to address the needs of these specific target groups. The possibility of making use of mobile applications or messages within the workplace programme, especially targeting the younger generation, should be investigated.

Although a large number of employees with high-risk behaviour might be aware of their risk, data also suggest that a larger proportion of the skilled and semi-skilled workforce do not use condoms because they trust their partners. Individuals' knowledge of HIV transmission and accurate assessment of their own risk seem to be two of the key factors in adoption of safer sexual practices (UNAIDS, 2001). The relationship between perception of risk and sexual behaviour is, however, complex and a wide range of variables seem to be responsible, such as number of sexual partners, knowledge of sexual partners' past sexual behaviour, fear of AIDS, shame associated with having AIDS, community perception of AIDS risk, knowing someone with AIDS, discussing AIDS at home, closeness of parent-child relationships and religious affiliation (Prohaska, Albrecht, Levy, Sugrue \& Kim, 1990).

Interventions in the workplace might therefore have to focus on creating an environment where employees can reflect on their actual risks. The often-discussed problem of using condoms as a sign of mistrust (Varga, 1997) might have to be addressed, including encouraging HIV testing for married and regular partners. With HIV prevalence being high in South Africa, it is important to encourage condom use in all types of sexual relationships, including consensual and legal unions, since both married and unmarried individuals engage in risky sexual behaviours, 
like multiple partners and unprotected sex with nonregular partners, as the collected data suggest.

Earlier research in the manufacturing sector in South Africa indicates that HIV prevalence rates may differ across different skill categories, with different effects on the labour force at different skill levels (Arndt \& Lewis, 2000). This is confirmed by results from several studies (BER, 2001; Quattek, 2000; Shisana \& Simbayi, 2002) indicating HIV prevalence rates of $26 \%-33 \%$ for unskilled and semi-skilled labour compared to $11 \%-17 \%$ in highly skilled groups. Although HIV status was not measured in this study, it is evident from the risk behaviour that all skill levels may be at risk of HIV transmission. It is therefore important to urgently incorporate the results of this study into workplace programmes, investigate changing the delivery systems of current risk reduction messages and their language, or targeting the unskilled groups on a more regular basis to address the unique needs that may be present.

Findings from this study also indicate that stigma still plays a major role in non-disclosure of HIV status amongst large proportions of employees, especially the unskilled labour force. Although employees seem to accept that a workplace policy is in place, and that HIV-positive employees should be supported, that knowledge does not translate into trusting their employer with their status. As stigma is documented as a barrier to uptake in HIV testing and treatment services in numerous settings in South Africa (Dlamini et al., 2009), the need for interventions to reduce the stigma in the workplace is evident. Literature recognises the link between training intervention, HIV and AIDS risk reduction and improved attitudes towards condom use (Becker, 2010; Chimbetete \& Gwandure, 2011, p. 16) and improved sexual risk cognition (Becker, 2010; Chimbetete \& Gwandure, 2011; East, Jackson, Peters \& O'Brien, 2010). More importantly, most studies indicate that HIV training programmes are strongly associated with a reduction in HIV-associated stigma and improved willingness to disclose HIV status (Chimbetete \& Gwandure, 2011; Gilbert \& Walker, 2010). Results from this study should be used as motivation to obtain buy-in from management to more strongly support implementation of HIV workplace programmes in the automotive industry.

\section{Practical implications}

According to a review by Mahajan et al. (2007) a 'wide variation in workplace policies and programmes is currently in place in southern Africa' and it is difficult to assess the effectiveness of workplace interventions at firm level. Current HIV and AIDS workplace programmes in organisations may include the institution of an HIV and AIDS policy, HIV counselling and testing and HIV prevention strategies including provision of condoms and antiretroviral therapy. However, in the companies that participated in this study, HIV and AIDS policies were developed but no specific workplace programmes are yet in place that would aim to implement for example, effective HIV prevention strategies, provision of regular access to HIV testing, provision of treatment and care or monitored referral systems. It is evident that despite HIV fatigue becoming more and more of a reality according to the Higher Education HIV and AIDS Programme (HEAIDS, 2010), employees across all skill levels could benefit from HIV workplace programmes to improve HIV risk behaviour and reduce stigma.

The results suggest that companies should invest in HIV prevention activities to positively influence risk behaviour, further reduce stigma and hopefully reduce future costs of HIV to the workplace, although there is no means by which to predict the effectiveness of such an investment (George et al., 2014). Still, the need for intervention seems evident as the majority of the workforce is particularly vulnerable, being in the age group most susceptible to HIV infection. The results of this study also suggest that more targeted interventions needs to be developed specifically focusing on the risk behaviour of employees of the different age groups, both genders and different cultural and educational backgrounds. Standardised interventions that do not take these differences into account might just add to the widespread AIDS fatigue. The use of standardised KAPB studies may provide important information to companies' management in this regard and the data they provide should be carefully analysed to inform the design of interventions and to trigger the development of target-specific interventions. The data collection is furthermore an important prerequisite to measure the changes in HIV risk behaviour and more importantly the prevalence of HIV-associated stigma, which may negatively impact on employee morale. Caution is necessary to interpret results as there may be cultural, linguistic and socio-economic aspects different to those of the research team that is implementing the KAPB studies. It is important to also obtain an adequate understanding of the context in which public health programmes are implemented, before implementing and interpreting KAPB studies. The authors strongly believe that KAPB studies can add value and provide relevant information to change attitudes, beliefs and stigma within the automotive industry. All automotive companies that participated in this study had HIV policies in place but no functioning workplace programmes. More than $30 \%$ of employees were unaware of existing policies, with large numbers still believing that they would lose their job if their HIV status was known to the employer. A multiple-method design, including focus group discussions together with the survey questionnaire, may be more accurate to understand the logic of participants. However, as more scientific evidence is needed to prove the effectiveness and efficiency of interventions, the data collected in this study will hopefully serve as baseline information to measure the success of such interventions in future studies. However, to change perceptions, active participation from management will be paramount in order to improve the legitimacy of these programmes.

\section{Limitations}

HIV status has not been determined in this study and therefore no associations could be determined between HIV prevalence and HIV-associated stigma. 
Respondents in studies dealing with sensitive topics and in the context of corporate environments might believe that the information will be used against them. Respondents might have given normative or socially appropriate answers based on what they think they should answer. The survey approach limits the responses of the respondent to selecting from a handful of predetermined responses and does not allow the respondent to give an answer that is not predetermined by the researcher. Because participation is voluntary, people in some cases chose to not answer some questions, which resulted in an unevenness in the response rate to different questions.

\section{Conclusion}

HIV risk behaviour is still a concern in smaller automotive companies and needs to be addressed as part of HIV workplace programmes. Although differences in risk behaviour and attitudes towards condom use have been established amongst the different skill levels, risk behaviour is still present at management level and workplace programmes should thus be aimed at all skill levels. HIVassociated stigma is still present in automotive companies despite the fact that all the South African companies that participated in this survey have adopted an HIV policy. KAPB studies may still be relevant to assess knowledge and attitudes about practices in general in the automotive industry, but it is important to carefully analyse the data and to contextualise the results to develop interventions that are tailored to the target group. Using KAPB surveys to monitor the effectiveness of interventions might fill a gap where insufficient evidence seems to exist about the success of such interventions not only to change employees' risk behaviour and to reduce stigma, but to also positively influence the profitability of the automotive industry. Without a proven economic benefit, company managers may continue to be reluctant in giving the necessary buy-in for HIV and AIDS workplace programmes.

\section{Acknowledgements}

This work was conducted in 2011 and 2012 during a project run by the AIDC EC and the Deutsche Gesellschaft für Internationale Zusammenarbeit (GIZ) $\mathrm{GmbH}$, a technical development agency owned by the German government. Many thanks to the AIDC EC and GIZ. Many thanks also to the participating companies for permission to publish these findings.

\section{Competing interests}

The authors declare that they have no financial or personal relationship(s) that may have inappropriately influenced them in writing this article.

\section{Authors' contributions}

L.S. (Nelson Mandela Metropolitan University) was responsible for the data interpretation and drafting of the article. J.v.d.M. (Nelson Mandela Metropolitan University) was responsible for the study proposal and subsequently the study rationale in the article. J.P. (Nelson Mandela Metropolitan University) was involved in the statistical analysis and result section, whilst F.B-W. (Nelson Mandela Metropolitan University), who was originally working at GIZ during data collection, contributed to a huge extent to the discussion section.

\section{References}

Acott, D. (2000). The impact of Aids in SA: a critique of demographic methods used in the ING Barings report of April 2000, and their implications. Unpublished honours thesis, University of Cape Town, Cape Town, South Africa.

Arndt, C., \& Lewis, J.D. (2000). The macro implications of HIV/AIDS in South Africa: A preliminary assessment. Presented at the International AIDS Economic Network (IAEN) Symposium on the Economics of HIV/AIDS in Developing Countries, Durban, South Africa, 07-08 July 2000.

Automotive Industry Development Care - Eastern Cape (AIDC EC). (2009). Executive summary of the Impact of HIV/AIDS in the South African Automotive Sector 2009 Report. Retrieved September 09, 2013, from http://www.aidcec.co.za/ documents/research/aidc_research_abstract_2009.pdf

The Automotive Industry Export Council (AIEC). (2014). South African Automotive export manual 2014. Retrieved March 19, 2015, from http://www.aidc.co.za/ Case\%20Studies/AutomotiveExportManual2014\%20\%282\%29.pdf

Becker, K. (2010). Facilitating unlearning during implementation of new technology. Journal of Organizational Change Management, 23(3), 251-268. http://dx.doi. org/10.1108/09534811011049590

Bureau for Economic Research (BER). (2001). The macro-economic impact of HIV/ AIDS in South Africa. Economic Research Note. No. 10. Stellenbosch, South Africa: University of Stellenbosch.

Catania, J.A., Kegeles, S.M., \& Coates, T.J. (1990). Towards an understanding of risk behavior: An AIDS risk reduction model (ARRM). Health Education and Behavior, 17(1), 53-72. Abstract retrieved September 13, 2013, from http://heb.sagepub. com/content/17/1/53.abstract\#cited-by

Chimbetete, M., \& Gwandure, C. (2011). Impact of a workplace-based HIV and AIDS risk reduction training intervention. Journal of Human Ecology, 35(1), 11-19.

Colvin, M., Connolly, C., \& Madurai, L.M. (2007). The epidemiology of HIV in South African workplaces. AIDS, 21(Suppl. 3), S13-S19. Abstract retrieved September 09 2013, from PubMed database: http://www.ncbi.nlm.nih.gov/pubmed/17666957

Department of Health. (2008). The national HIV and syphilis prevalence survey South Africa. South Africa: Department of Health.

Department of Labour. (2000). Employment Equity Act, 1998 (Act no. 55 of 1998) Code of Good Practice on Key Aspects of HIV/AIDS and Employment. Government Gazette, No. 21815.

Dlamini, P.S., Wantland, P., Makoae, L.N., Chirwa, M., Kohi, T.W., Greeff, M. et al. (2009) HIV stigma and missed medications in HIV-positive people in five African countries. AIDS Patient Care ST, 23(5), 377-387. http://dx.doi.org/10.1089/apc.2008.0164

East, L., Jackson, D., Peters, K., \& O’Brien, L. (2010). Disrupted sense of self: young women and sexually transmitted infections. Journal of Clinical Nursing, 19, 1995-2003. http://dx.doi.org/10.1111/j.1365-2702.2009.03183.x

Eastern Cape Development Corporation (ECDC). (2013). Automotives and components Retrieved November 19, 2013, from http://www.ecdc.co.za/ecdc/opportunities/ manufacturing

Fraser, F.K., Grant, W.J., Mwanza, P., \& Naidoo, V. (2002). The impact of HIV/AIDS on small and medium enterprises in South Africa. South African Journal of Economics, 70(7), 575-583. Abstract retrieved September 11, 2013, from http://onlinelibrary. wiley.com/, doi/10.1111/j.1813-6982.2002.tb01191.x/abstract

George, G., Surgey, G., \& Gow, J. (2014). South Africa's private sector investment in training and its erosion as a result of HIV and AIDS. South African Journal of Economic and Management Sciences, 17(2), 109-123.

Gilbert, L., \& Walker, L. (2010). 'My biggest fear was that people would reject me once they knew my status': Stigma as experienced by parents in a HIV/AIDS clinic in Johannesburg, South Africa. Health and Social Care in the Community, 18(2), 139-146. Retrieved October 05, 2013 from http://www.ncbi.nlm.nih.gov/ 18(2), 139-146. Retrie

Global Business Coalition (GBC) and International Finance Corporation (IFC). (2010). Fighting HIV/AIDS in the workplace: A company management guide. Retrieved August 20, 2014, from http://www.gbchealth.org/system/documents/ category_13/91/Fighting-HIVAIDS-in-Workplace.pdf?1315342567

Hatzenbuehler, M.L., Phelan, J.C., \& Link, B.G. (2013). Stigma as a fundamental cause of population health inequalities. American Journal of Public Health, 103(5), 813-821. http://dx.doi.org/10.2105/AJPH.2012.301069

Health Systems Trust. (2013). South African Health Review 2012/2013. Retrieved August 18, 2014, from http://www.hst.org.za/publications/south-african-healthreview-2012/13

Higher Education HIV and AIDS Programme (HEAIDS). (2010). An investigation of graduate competency for managing HIV/AIDS in the workplace. Pretoria, Gauteng South Africa: Higher Education South Africa.

ILO. (2009). Facts on HIV and work. Retrieved September 09, 2013, from http://www. ilocarib.org.tt/images/stories/contenido/pdf/Fact $\% 20$ Sheets/Fact $\% 20$ Sheet $\% 20$ HIV.pdf 
International Labour Organization (ILO). (2006). HIV/AIDS and work: Global estimates, impact on children and youth, and response. Switzerland: International Labour impact
Office.

International NGO Training and Research Centre (INTRAC). (2008). Praxis Note No. 38. Denial, fear and fatigue: The emotional blocks to addressing HIV/AIDS in the workplace. Durban, South Africa: INTRAC.

Johannesburg Motor Show. (2013). SA auto industry. Retrieved November 19, 2013 , from http://www.jhbmotorshow.co.za/index.php/rooms

Joint United Nations Programme on AIDS (UNAIDS). (1999). Sexual behaviour change for HIV: Where have the theories taken us? Geneva, Switzerland: UNAIDS.

Joint United Nations Programme on AIDS (UNAIDS). (2001). HIV prevention needs and successes: A tale of three countries. An update on HIV prevention success in Senegal, Thailand and Uganda. Geneva, Switzerland: UNAIDS.

Joint United Nations Programme on AIDS (UNAIDS). (2003). Accelerating action against AIDS in Africa. Geneva, Switzerland: UNAIDS.

Link, B.C., \& Phelan, J. (1995). Social conditions as a fundamental cause of disease. Journal of Health and Social Behavior, 80-94. http://dx.doi.org/10.2307/2626958

Link, B.C., \& Phelan, J.C. (2001). Conceptualizing stigma. Annual Review of Sociology, 27, 363-385. http://dx.doi.org/10.1146/annurev.soc.27.1.363

Lisk, F. (2002). Labour market and employment implications of HIV/AIDS. Retrieved September 11, 2013, from http://www.ilo.org/public/english/region/eurpro/ moscow/areas/aids/wp1_labourmarket.pdf

Mahajan, A.P., Colvin, M., Rudatsikira, J.B., \& Ettl, D. (2007). An overview of HIV/ AIDS workplace policies and programmes in southern Africa. AIDS, 21 (Suppl. 3), S31-S39. Retrieved October 05, 2013, from http://journals.Iww.com/aidsonline/ toc/2007/06003

Mahajan, A.P., Sayles, J.N., Patel, V.A., Remien, R.H., Ortiz, D., Szekeres G. et al. (2008) Stigma in the HIV/AIDS epidemic: A review of the literature and recommendations for the way forward. AIDS, 22 (Suppl. 2), S67-S79. http://dx.doi.org/10.1097/01. aids.0000327438.13291.62

Maughan-Brown, B. (2010). Stigma rises despite antiretroviral roll-out: A longitudinal analysis in South Africa. Social Science \& Medicine, 70(3), 368-374. http://dx.doi. org/10.1016/j.socscimed.2009.09.041

Meyer-Weitz, A., Weihs, M., \& Baasner-Weihs, F. (2012). Wellness workplace programmes as a platform to fight HIV and AIDS: Automotive manufacturing sector in South Africa. Poster presentation at the SAAIDS Conference 2012 Durban, South Africa, June.

National Association of Automobile Manufacturers of South Africa (NAAMSA). (2013). Quarterly review of business conditions: Motor vehicle manufacturing industry/ automotive sector: 2nd Quarter 2013. Message posted to representatives at general meetings and recipients of NAAMSA media releases. Retrieved August 20 general meetings and recipients of NAAMSA media releases. Retrieved August 20, QUARTERLY\%20REVIEW\%20\%20-\%20\%202ND\%20QUARTER\%202013.pdf

National Treasury. (2013). Estimates of national expenditure 2013. Pretoria, South Africa: National Treasury.

Neilson, T. (2005). Should your business fight HIV/AIDS? Retrieved September 24, 2014 from http://skollworldforum.org/2006/09/25/corporate-socialresponsibility-and-social-entrepreneurs/

Noar, S.M. (2007). An interventionist's guide to AIDS behavioral theories. AIDS Care, 19(3), 392-402. http://dx.doi.org/10.1080/09540120600708469

Price Waterhouse Coopers. (2013). Business decision makers' survey on HIV and AIDS. Namibia: Price Waterhouse Coopers. Retrieved August 28, 2014, from http://www.pwc.com/na/en/publications/business-decision-makers-survey-onhiv-and-aids.jhtml

Prohaska, T.R., Albrecht, G., Levy, J.A., Sugrue, N., \& Kim, J.-H. (1990). Determinants of self-perceived HIV risk for AIDS. Journal of Health and Social Behavior, 31, 384-394. http://dx.doi.org/10.2307/2136821
Quattek, K. (2000). The economic impact of AIDS on South Africa: A dark cloud on the horizon. In K. Adenauer-Stiftung (Ed.), HIV/AIDS: A threat to the African Renaissance?, (pp. 29-56). Johannesburg, South Africa: Konrad Adenauer Stiftung.

Rosen, S., Feeley, F., Connelly, P., \& Simon, J. (2007). The private sector and HIV/ AIDS in Africa: Taking stock of 6 years of applied research. AIDS, 21 (Suppl. 3) S41-S51. Abstract retrieved September 11, 2013, from http://www.ncbi.nlm.nih. gov/pubmed/17666961

Rukambe, Z. (2010). Employees' knowledge, attitudes and practices around HIV/AIDS at the Rosh Pinah Zinc Mine, Namibia. Master's thesis, University of the Witwatersrand, Johannesburg, South Africa.

Setswe, G.K.G. (2009, July). Best practice workplace HIV/AIDS programmes in South Africa: A review of case studies and lessons learned. African Journal of Primary Health Care \& Family Medicine, 1, 1. Retrieved August 18, 2014, from http://www.phcfm.org/index.php/phcfm/article/view/30

Shisana, O., Rehle, T., Simbayi, L.C., Zuma, K., Jooste, S., Zungu, N. et al. (2014). South African national HIV prevalence, incidence and behaviour survey, 2012. Cape Town, South Africa: HSRC Press.

Shisana, O., \& Simbayi, L. (2002). South African national HIV prevalence, behavioural risks and mass media household survey 2002. Cape Town, South Africa: HSRC Press.

South African Business Coalition on HIV and AIDS (SABCOHA). (2012). HIV, AIDS, TB and wellness. Eastern Cape business sector provincial strategic plan 2012-2016. Johannesburg, South Africa: SABCOHA.

South African Business Coalition on HIV and AIDS (SABCOHA). (2014). HIV \& business overview. Retrieved November 21, 2013, from http://www.sabcoha.org/hivbusiness-overview/

South African Business Coalition on HIV and AIDS (SABCOHA), \& Bureau for Economic Research (BER). (2003). The economic impact of HIV/AIDS on business in South Africa. Johannesburg, South Africa: BER/SABCOHA.

Sprague, L., Simon, S., \& Sprague, C. (2011). Employment discrimination and HIV stigma: survey results from civil society organisations and people living with HIV in Africa. African Journal of AIDS Research, 10(3), S311-S324. Abstract retrieved August 28, 2014, from http://www.tandfonline.com/doi/abs/10.2989/16085906. 2011.637730\#.U_8hf2PySSo

Thurlow, J., Gow, J., \& George, G. (2009). HIV/AIDS, growth and poverty in KwaZuluNatal and South Africa: An integrated survey, demographic and economy-wide analysis. Journal of the International AIDS Society, 12, 18. Retrieved August 19, 2014 from http://www.ncbi.nlm.nih.gov/pmc/articles/PMC2754430/

United Nations Department of Economic and Social Affairs, Population Division. (2009). The impact of AIDS. Retrieved September 07, 2013, from http://www. un.org/esa/population/publications/AIDSimpact/7_Chap_IV.pdf

Van Brakel, W.H. (2006). Measuring health-related stigma a literature review. Psychology, Health, \& Medicine, 11, 307-334. http://dx.doi.org/10.1080/ 13548500600595160

Van Zyl, G., \& Lubisi, C. (2009). HIV/AIDS in the workplace and the impact on firm efficiency and firm competitiveness: The South African manufacturing industry as a case study. SA Journal of Human Resource Management/SA Tydskrif vir Menslikehulpbronbestuur, 7(1), Art. \#206. Retrieved September 09, 2013, from http://www.sajhrm.co.za/index.php/sajhrm/article/viewFile/206/204

Varga, C.A. (1997). The condom conundrum: Barriers to condom use among commercial sex workers in Durban, South Africa. African Journal of Reproductive Health, 1(1), 74-88. http://dx.doi.org/10.2307/3583277

Weihs, M., \& Meyer-Weitz, A. (2014). A lottery incentive system to facilitate dialogue and social support for workplace HIV counselling and testing: A qualitative inquiry. Journal of Social Aspects of HIV/AIDS, 11(1), 116-125. http://dx.doi.org/10.1080 /17290376.2014.937739

World Health Organization. (2008). A Guide to Developing Knowledge, Attitude and Practice Surveys. Retrieved March 02, 2011, from http://www.who.int/tb/ people_and_communities/advocacy_communication/en/index.html 